Article

\title{
Surface Phenotype Changes and Increased Response to Oxidative Stress in $\mathrm{CD} 4^{+} \mathrm{CD} 25^{\text {high }} \mathrm{T}$ Cells
}

\author{
Yoshiki Yamamoto ${ }^{1, *}$, Takaharu Negoro ${ }^{2}$, Rui Tada ${ }^{3} \mathbb{D}$, Michiaki Narushima $^{4}$, Akane Hoshi ${ }^{2}$, Yoichi Negishi ${ }^{3, *}$ \\ and Yasuko Nakano ${ }^{2}$
}

check for

updates

Citation: Yamamoto, Y.; Negoro, T.; Tada, R.; Narushima, M.; Hoshi, A.; Negishi, Y.; Nakano, Y. Surface Phenotype Changes and Increased Response to Oxidative Stress in $\mathrm{CD} 4^{+} \mathrm{CD} 25^{\text {high }} \mathrm{T}$ Cells. Biomedicines 2021, 9, 616. https://doi.org/ $10.3390 /$ biomedicines 9060616

Academic Editor: Juan Gambini

Received: 7 May 2021

Accepted: 25 May 2021

Published: 29 May 2021

Publisher's Note: MDPI stays neutral with regard to jurisdictional claims in published maps and institutional affiliations.

Copyright: (c) 2021 by the authors. Licensee MDPI, Basel, Switzerland. This article is an open access article distributed under the terms and conditions of the Creative Commons Attribution (CC BY) license (https:/ / creativecommons.org/licenses/by/ $4.0 /)$.
1 Department of Paediatrics, Tokyo Metropolitan Ebara Hospital, Tokyo 145-0065, Japan

2 Department of Pharmacogenomics, School of Pharmacy, Showa University, Tokyo 142-8555, Japan; tanego@pharm.showa-u.ac.jp (T.N.); rubiaceae1122@yahoo.co.jp (A.H.); yasueco.nakano@gmail.com (Y.N.)

3 Department of Drug Delivery and Molecular Biopharmaceutics, School of Pharmacy, Tokyo University of Pharmacy and Life Sciences, Tokyo 192-0392, Japan; rui.tada@gmail.com

4 Department of Internal Medicine, Showa University Northern Yokohama Hospital, Kanagawa 224-8503, Japan; narushiz@gmail.com

* Correspondence: laphroaig27aug12@gmail.com (Y.Y.); negishi@toyaku.ac.jp (Y.N.); Tel.: +81-3-5734-8000 (Y.Y.); +81-42-676-3182 (Y.N.)

\begin{abstract}
Conversion of $\mathrm{CD}^{+}{ }^{+} \mathrm{CD} 25^{+} \mathrm{FOXP}^{+}{ }^{+} \mathrm{T}$ regulatory cells $\left(\mathrm{T}_{\text {regs }}\right)$ from the immature $\left(\mathrm{CD} 4 \mathrm{RA}^{+}\right)$ to mature $\left(\mathrm{CD} 45 \mathrm{RO}^{+}\right)$phenotype has been shown during development and allergic reactions. The relative frequencies of these $\mathrm{T}_{\text {reg }}$ phenotypes and their responses to oxidative stress during development and allergic inflammation were analysed in samples from paediatric and adult subjects. The FOXP3 ${ }^{\text {low }} \mathrm{CD} 45 \mathrm{RA}^{+}$population was dominant in early childhood, while the percentage of FOXP3 ${ }^{\text {high }} \mathrm{CD} 45 \mathrm{RO}^{+}$cells began increasing in the first year of life. These phenotypic changes were observed in subjects with and without asthma. Further, there was a significant increase in phosphorylated ERK1/2 (pERK1/2) protein in hydrogen peroxide $\left(\mathrm{H}_{2} \mathrm{O}_{2}\right)$-treated CD4 ${ }^{+} \mathrm{CD} 25^{\text {high }}$ cells in adults with asthma compared with those without asthma. Increased $p E R K 1 / 2$ levels corresponded with increased $\mathrm{Ca}^{2+}$ response to $\mathrm{T}$ cell receptor stimulation. mRNA expression of peroxiredoxins declined in $\mathrm{T}_{\text {regs }}$ from adults with asthma. Finally, $\mathrm{CD} 4{ }^{+} \mathrm{CD} 25^{\text {high }}$ cells from paediatric subjects were more sensitive to oxidative stress than those from adults in vitro. The differential $\mathrm{T}_{\text {reg }}$ sensitivity to oxidative stress observed in children and adults was likely dependent on phenotypic CD45 isoform switching. Increased sensitivity of $\mathrm{T}_{\text {reg }}$ cells from adults with asthma to $\mathrm{H}_{2} \mathrm{O}_{2}$ resulted from a reduction of peroxiredoxin-2, $-3,-4$ and increased pERK1/2 via impaired $\mathrm{Ca}^{2+}$ response in these cells.
\end{abstract}

Keywords: allergy; CD45 isoform; extracellular signal-regulated kinases 1/2; oxidative stress; regulatory $\mathrm{T}$ cell

\section{Introduction}

Regulatory $\mathrm{T}$ cells $\left(\mathrm{T}_{\text {regs }}\right)$ play critical roles in allergic immune response regulation [1-3]. Airway inflammation in paediatric asthma is associated with infiltrating Th2 cells and eosinophils triggered by allergens [4], and most children with asthma are atopic in Japan [5]. Numerous studies have shown that reduced $T_{\text {reg }}$ cells [6], decreased levels of forkhead box P3 (FOXP3) protein, a master transcriptional regulator of $\mathrm{T}_{\text {reg }}$ cells [6-9], and impaired $\mathrm{T}_{\text {reg }}$ function result in the loss of control of inflammation [8,10-12]. However, several reports have demonstrated increases in the number of $\mathrm{T}_{\text {regs }}$ during exacerbation of asthma $[13,14]$ and elevated $\mathrm{T}_{\text {reg }}$ numbers and FOXP3 expression after allergen challenge [15] or glucocorticoid treatment $[7,16,17]$.

Studies have identified that several $\mathrm{T}_{\text {reg }}$ subtypes, such as thymus-derived $\mathrm{T}_{\text {regs }}$ $\left(\mathrm{tT}_{\text {regs }}\right)$ and peripherally derived $\mathrm{T}_{\text {regs }}\left(\mathrm{pT}_{\text {regs }}\right)$, are involved in the regulation of airway inflammation [18-20]. $\mathrm{T}_{\text {reg }}$ maturation that occurs during development can be detected by a shift in the expression of isoforms of the CD45 surface antigen from CD45RA to 
CD45RO. This phenotypic switch is a marker of $\mathrm{T}$ cell differentiation [21-23]: CD45RA ${ }^{+}$ expression is characteristic of naïve $\mathrm{T}$ cells before antigen exposure, whereas $\mathrm{CD} 45 \mathrm{RO}^{+} \mathrm{T}$ cells are memory $\mathrm{T}$ cells that have been exposed to antigen. Miyara et al. demonstrated that immature FOXP3 ${ }^{\text {low }} \mathrm{CD} 45 \mathrm{RA}^{+} \mathrm{T}_{\text {reg }}$ cells could differentiate to mature FOXP3 ${ }^{\text {high }} \mathrm{CD} 45 \mathrm{RA}^{-}$ $\mathrm{T}_{\text {reg }}$ cells, which were very similar to $\mathrm{CD} 45 \mathrm{RO}^{+} \mathrm{T}_{\text {reg }}$ cells [23]. The cells with the immature phenotype accounted for a substantial fraction of $\mathrm{T}_{\text {reg }}$ cells in children, whereas the cells with the mature phenotype were dominant in adults. Whereas numerous studies have assessed $\mathrm{T}_{\text {reg }}$ subtypes in the cord blood and adult peripheral blood, $\mathrm{T}_{\text {reg }}$ CD45 isoform phenotypic switching during early childhood development has not been examined in allergic subjects. Thus, here we compared changes during development and those with regard to allergies in early childhood.

Mougiakakos et al. reported that the production of high levels of thioredoxin- 1 by $\mathrm{T}_{\text {reg }}$ cells conferred protection against cell death triggered by hydrogen peroxide $\left(\mathrm{H}_{2} \mathrm{O}_{2}\right)$ mediated oxidative stress [24]. $\mathrm{H}_{2} \mathrm{O}_{2}$ induces several cellular responses, including the activation of MAP kinase, chemokine production, and apoptosis [24-26]. In this study, tolerance to oxidative stress in $\mathrm{T}_{\text {regs }}$ was compared in paediatric subjects with and without allergy by the assessment of phosphorylation of extracellular signal-regulated kinase $1 / 2$ (ERK1/2) and p38 mitogen-activated protein kinase (p38 MAPK). Moreover, adults with or without asthma were compared with paediatric subjects. Finally, antioxidant stress-related patterns of gene expression were assessed by microarray profiling of Jurkat cells with doxycyline (Dox)-inducible FOXP3.

\section{Materials and Methods}

\subsection{Subjects}

Paediatric subjects, 11 with and 38 without allergy, were recruited at the Showa University Hospital and Tokyo Metropolitan Ebara Hospital between July and December 2004 and between December 2006 and January 2007. Characteristics of all the paediatric subjects are shown in Table 1 . The age of paediatric subjects with allergy ranged from 11 months to 13 years and 3 months, and the average age was 4 years and 8 months. The age of paediatric subjects without allergy ranged from 3 months to 8 years and 2 months, and the average age of this group was comparable to that of the allergic paediatric cases. Allergic diseases mainly consist of asthma, allergic rhinitis, atopic dermatitis, and food allergy. The majority of allergic subjects had two or more allergic diseases, and eight of these had simultaneous food allergy and atopic dermatitis. Adult subjects, 10 with and 6 without asthma, were recruited at Showa University Hospital and Showa University Fujigaoka Hospital between July and October 2004 (Table 1). Asthma was defined according to the criteria established by the 1998 Japanese guidelines, the Japanese Pediatric Guidelines for the Treatment and Management of Asthma 2004, and the Global Initiative for Asthma as revised in 2002. Atopic dermatitis and food allergy were defined according to the criteria established by the Japanese Guideline for Atopic Dermatitis 2004 and the Japanese Guideline for Diagnosis and Management of Food Allergy 2005, respectively. All subjects with allergy completed a standard questionnaire regarding allergy symptoms, and atopy was established by the measurement of serum-specific IgE to common allergens such as mite, mold, pet allergens, pollen, and food allergens (CAP RAST system; Pharmacia Diagnostics AB, Uppsala, Sweden). This study was approved by the Showa University Medical Ethics Committee (protocol number 310 for paediatric subjects, protocol number 2002022 for adult subjects) and the Tokyo Metropolitan Ebara Hospital Trust local research and ethics committee. Written informed consent was obtained from all participants or their guardians in accordance with the ethical guidelines of the Declaration of Helsinki: The Materials and Methods should be described with sufficient details to allow others to replicate and build on the published results. Please note that the publication of your manuscript implicates that you must make all materials, data, computer code, and protocols associated with the publication available to readers. Please disclose at the submission stage any restrictions on the availability of materials or information. New methods and protocols 
should be described in detail while well-established methods can be briefly described and appropriately cited.

Research manuscripts reporting large datasets that are deposited in a publicly available database should specify where the data have been deposited and provide the relevant accession numbers. If the accession numbers have not yet been obtained at the time of submission, please state that they will be provided during review. They must be provided prior to publication.

Interventionary studies involving animals or humans, and other studies that require ethical approval, must list the authority that provided approval and the corresponding ethical approval code.

Table 1. Clinical characteristics of study subjects.

\begin{tabular}{|c|c|c|c|c|}
\hline & \multicolumn{2}{|c|}{ Child } & \multicolumn{2}{|c|}{ Adult } \\
\hline & $\begin{array}{l}\text { Allergy } \\
(n=38)\end{array}$ & $\begin{array}{l}\text { Non-Allergy } \\
\quad(n=11)\end{array}$ & $\begin{array}{l}\text { Asthma } \\
(n=10)\end{array}$ & $\begin{array}{l}\text { Non-Asthma } \\
\quad(n=6)\end{array}$ \\
\hline Age & $4.7 \pm 3.5$ & $4.0 \pm 2.6$ & $51.1 \pm 20.1$ & $29.3 \pm 6.8$ \\
\hline Gender (male/female) & $28 / 10$ & $6 / 5$ & $6 / 4$ & $4 / 2$ \\
\hline \multicolumn{5}{|l|}{ Type } \\
\hline Atopic & 38 & & 8 & \\
\hline Nonatopic & 0 & & 2 & \\
\hline \multicolumn{5}{|l|}{ Asthma severity } \\
\hline Step 1 & 2 & & & \\
\hline Step 2 & 9 & & 3 & \\
\hline Step 3 & 11 & & 7 & \\
\hline Step 4 & 4 & & & \\
\hline Food allergy & $15(3) * 1$ & & & \\
\hline Atopic dermatitis & $13(7) * 2$ & & & \\
\hline Allergic rhinitis & 2 & & & \\
\hline Dose of ICS & & & \multirow{3}{*}{\multicolumn{2}{|c|}{$492(400-1600)$}} \\
\hline CFC-BDP mg/day & $183(0-800)$ & & & \\
\hline Smoking & & & & \\
\hline Nonsmoker & & & 7 & 6 \\
\hline Current smoker & & & 3 & 0 \\
\hline
\end{tabular}

\subsection{Flow Cytometry \\ 2.2.1. Cells}

Peripheral blood mononuclear cells (PBMCs) were prepared by density gradient centrifugation using Lymphoprep ${ }^{\mathrm{TM}}$ (Axis-Shield PoC AS, Oslo, Norway) according to previously reported protocols $[11,12]$. $\mathrm{CD}^{+} \mathrm{T}$ cells were isolated from PBMCs using a MACS CD4 $4^{+}$T cell isolation kit II (Miltenyi Biotec, Bergisch Gladbach, Germany) according to the manufacturer's instructions, and $\mathrm{CD} 4^{+} \mathrm{CD} 25^{+} \mathrm{CD} 127^{\text {low }} \mathrm{T}$ cells were isolated as described previously [12].

\subsubsection{Surface Marker Analysis in $\mathrm{CD} 4^{+} \mathrm{CD} 25^{+} \mathrm{FOXP} 3^{+} \mathrm{T}$ Cells}

Purified CD4 ${ }^{+} \mathrm{T}$ cells $\left(1 \times 10^{6}\right.$ cells) were suspended in $1 \mathrm{~mL}$ fixation solution (5\% paraformaldehyde and $0.5 \%$ Tween 20 in phosphate buffered saline [PBS]) and stored overnight at $4{ }^{\circ} \mathrm{C}$. Intracellular FOXP3 staining was performed by anti-FOXP3 monoclonal antibodies (mAbs) conjugated to different fluorochromes, as described previously [26]. To analyse surface antigen expression, staining with Alexa Fluor ${ }^{\circledR} 488$-FOXP3 mAb was followed by staining for one of the following dual staining paradigms: PE-labelled CD25 (M-A251) plus PC5-labelled CD127, PC5-labelled CD25 (B1.49.9) plus PE-labelled CD45RO (UCHL1), or PC5-labelled CD25 plus PE-labelled CD45RA (HI100). When unlabelled antiFOXP3 (259D) and biotin-conjugated anti-CD127 (eBiRD5) mAbs (all antibodies were from eBioscience, Inc., San Diego, CA, USA) were used as primary antibodies, cells 
were incubated with Alexa Fluor ${ }^{\circledR}$ 488- or PC5-streptavidin-labelled secondary antibodies, respectively. The cells were incubated with either non-conjugated or fluorochromeconjugated antibodies for $15 \mathrm{~min}$ at $4{ }^{\circ} \mathrm{C}$. Alexa Fluor ${ }^{\circledR} 488$-secondary antibody, PE-CD25, PC5-streptavidin, PE-CD45RO, and PE-CD45RA antibodies were obtained from BD Biosciences (Franklin Lakes, NJ, USA) and PC5-CD25 and streptavidin-PC5 antibodies were obtained from Beckman Coulter (Pasadena, CA, USA). The samples were suspended in $350 \mu \mathrm{L}$ fluorescence-activated cell sorting (FACS) buffer (PBS, 5\% fetal bovine serum [FBS], $2 \mathrm{mM}$ EDTA and $0.1 \%$ sodium azide) and were analysed by flow cytometry using EPICS XL (Beckman Coulter). The data were analysed by FlowJo software (TreeStar, Ashland, OR, USA). Gating was performed on cells that were highly expressing CD25 (CD25 high) to increase $\mathrm{T}_{\text {reg }}$ purity, as the intracellular phosflow labeling was not compatible with FOXP3 co-staining. In the other analyses, CD25 positive cells including both CD25 low and $\mathrm{CD} 25^{\text {high }}$ were gated as $\mathrm{CD} 25^{+}$.

\subsection{Phosphorylation of ERK1/2 and $p 38 M A P K$}

Activation of cellular signaling in $\mathrm{CD} 4^{+} \mathrm{CD} 25^{\text {high }} \mathrm{T}$ cells in response to oxidative stress was analysed using BD Phosflow technology (BD Biosciences). Briefly, $3 \times 10^{5}$ PBMCs were suspended in $15 \mu \mathrm{L}$ of 4-(2-hydroxyethyl)-1-piperazineethanesulfonic acid (HEPES)buffered saline (107 mM NaCl, $6 \mathrm{mM} \mathrm{KCl}, 1.2 \mathrm{mM} \mathrm{MgSO}_{4}, 2 \mathrm{mM} \mathrm{CaCl}, 1.2 \mathrm{mM} \mathrm{KH}_{2} \mathrm{PO}_{4}$, $11.5 \mathrm{mM}$ glucose, and $20 \mathrm{mM}$ HEPES adjusted to $\mathrm{pH} 7.4$ with $\mathrm{NaOH}$ ) containing $0.1 \%$ BSA and incubated with $\mathrm{H}_{2} \mathrm{O}_{2}$ at increasing concentrations from $10 \mu \mathrm{M}$ to $10 \mathrm{mM}$ for 10 min at $37^{\circ} \mathrm{C}$ with agitation at $350 \mathrm{rpm}$ using a reciprocal shaker. After oxidative stress induction, the reaction was stopped by fixing the cells with $250 \mu \mathrm{L}$ of Cytofix/Cytoperm solution (BD Biosciences) for $10 \mathrm{~min}$ at $37^{\circ} \mathrm{C}$. Cells were washed twice with Perm/Wash buffer (BD Biosciences) and resuspended in $50 \mu \mathrm{L}$ of Perm/Wash buffer. For the analysis of ERK1/2 or p38 MAPK phosphorylation in $\mathrm{CD} 4^{+} \mathrm{CD} 25^{\text {high }} \mathrm{T}$ cells, the following fluorescence labelling antibodies were added at $6 \mu \mathrm{L}$ each and incubated for $60 \mathrm{~min}$ at room temperature in the dark: PC5-CD4 (13B8.2; Beckman Coulter), PE-CD25 (M-A251; BD Biosciences), and Alexa488-pERK1/2 (T202/Y204) (612592; BD Biosciences) or Alexa 488-pp38 MAPK (T180/Y182) (612594; BD Biosciences). After washing with the Perm/Wash buffer, the cells were resuspended in $100 \mu \mathrm{L}$ of FACS buffer and analysed by flow cytometry.

\subsection{Measurement of Intracellular $\mathrm{Ca}^{2+}$ Influx}

Changes in intracellular $\mathrm{Ca}^{2+}$ influx $\left[\mathrm{Ca}^{2+}\right]_{i}$ were measured using the cell-permeable Fura-2 AM fluorescent dye, as described previously [12,27]. Images of Fura-2-loaded cells were analysed using a video image analyser (Meta Fulora; Nippon Ropper, Tokyo, Japan). Cytosolic $\mathrm{Ca}^{2+}$ concentrations were assessed by exciting the cells at 340 and $380 \mathrm{~nm}$ using the dual-wavelength excitation method and measuring fluorescence at $510 \mathrm{~nm}$. We have previously shown that $\mathrm{Ca}^{2+}$ responses were divided into two categories based on the ratio of peak fluorescence (340/380): poor $(<0.1)$ and robust $(>0.1)$ [12].

\subsection{Microarray Analysis}

RNA was isolated from cells using RNAiso Plus (Takara Bio. Inc., Shiga, Japan). Microarray analysis was performed using the 3D-Gene human oligo chip 25k (TORAY Industries, Tokyo, Japan). RNA sample quality was determined using an Agilent 2100 Bioanalyzer (Agilent Technologies, Santa Clara, CA, USA) and Nanodrop ${ }^{\circledR}$ (Thermo Fisher Scientific, Waltham, MA, USA). RNA amplification and Cy5-labeling were performed using Ambion Amino Allyl aRNA (Thermo Fisher Scientific) and Amersham Cy5 mono-reactive dye (GE Healthcare Bio-Sciences, Pittsburgh, PA, USA), respectively. The Cy5-labeled amplified RNA samples ( $1 \mu \mathrm{g}$ per sample) were hybridized at $37^{\circ} \mathrm{C}$ for $16 \mathrm{~h}$ and scanned using the 3D-Gene Scanner 3000 (TORAY). After subtracting background signal from raw data on each chip, the signal of each gene was normalized by the global normalisation method where the median of the detected signal intensity was adjusted to 25 . 
Microarray samples were selected and prepared as mentioned below. We have previously generated Jurkat Tet-On ${ }^{\circledR}$ cells with Dox-inducible FOXP3 protein expression: 5G1 cells are control cells, and F2A9 cells are derived from a Jurkat Tet-On ${ }^{\circledR}$ cell line with Dox-inducible FOXP3 [12]. F2A9 cells that were induced with Dox for two days for FOXP3 expression (FOXP3 2-day) demonstrated low $\left[\mathrm{Ca}^{2+}\right]_{i}$ in response to TCR stimulation, similar to that observed in $\mathrm{CD} 4{ }^{+} \mathrm{CD} 25^{+} \mathrm{T}$ cells from subjects without asthma. However, $\mathrm{Ca}^{2+}$ responsiveness in F2A9 cells induced with Dox for 5 days (FOXP3 5-day) was similar to that observed in cells from asthmatic subjects [12]. Samples were named Control 2-day, Control 5-day, FOXP3 2-day, and FOXP3 5-day.

Microarray data were analysed for antioxidant gene expression as illustrated by a HeatMap (Supplementary Figure S1). We focused on genes with increased expression in FOXP3 2-day compared with control 2-day, rather than 5-day versus FOXP3 5-day because of the FOXP3 2-day tolerability to oxidative stress. Since FOXP3 5-day is a model cell for asthma $\mathrm{T}_{\text {regs, }}$, the cells are considered more sensitive to oxidative stress than FOXP3 2-day (non-asthma $\mathrm{T}_{\text {regs }}$ ). We selected the genes that are able to scavenge reactive oxygen species (ROS) directly for further analyses.

\subsection{Real-Time Polymerase Chain Reaction}

RNA extraction, reverse transcription, and real-time polymerase chain reaction (RTPCR) were performed as described previously [12]. Peroxiredoxin-2 (Hs99999903_m1) were measured using specific TaqMan ${ }^{\circledR}$ probe primer sets (Life Technologies, Carlsbad, CA, USA), and the mRNA expression of peroxiredoxin-2 (Hs00853603_s1_M), -3 (Hs00428953_g1 _M), -4 (Hs 01056076_m1_M) and $\beta$-actin (NM_005809.5), -3 (NM_014098.3), -4 (NM_006406.1), and $\beta$-actin (NM_001101) were quantified using a StepOne ${ }^{\mathrm{TM}}$ Real-Time PCR system (Life Technologies). The expression of each gene was normalized to $\beta$-actin expression.

\subsection{Quantification of Glutathione}

Glutathione content was measured by the GSH-Glo ${ }^{\mathrm{TM}}$ glutathione assay (Promega, Madison, WI, USA) according to the manufacturer's instructions. Furthermore, $4 \times 10^{3}$ Jurkat cells were suspended in $50 \mu \mathrm{L}$ of PBS and mixed with $50 \mu \mathrm{L}$ of $2 \times \mathrm{GSH}-\mathrm{Glo}$ reagent. Cells were incubated for $30 \mathrm{~min}$ at room temperature. After the addition of $100 \mu \mathrm{L}$ luciferin detection reagent, cells were incubated for $15 \mathrm{~min}$ at room temperature. The luminescence was measured at $23^{\circ} \mathrm{C}$ with a Tecan Infinite ${ }^{\circledR} 200$ PRO multimode microplate reader.

\subsection{Measurement of Caspase Activity}

In total, $1 \times 10^{6}$ Jurkat cells were treated with either PBS or $100 \mu \mathrm{M} \mathrm{H}_{2} \mathrm{O}_{2}$ in $5 \mathrm{~mL}$ of RPMI 1640 media containing $0.1 \%$ BSA for $4 \mathrm{~h}$ in a $\mathrm{CO}_{2}$ incubator. The cells were washed twice with PBS, and the supernatants were removed. Caspase activity was measured by the fluorimetric SensoLyte ${ }^{\circledR} 520$ generic caspase assay (AnaSpec, Fremont, CA, USA) according to the manufacturer's instructions. Briefly, cells were resuspended in $300 \mu \mathrm{L}$ of RPMI 1640 media containing $0.1 \%$ BSA in a $2 \mathrm{~mL}$ tube and incubated with $10 \mu \mathrm{L}$ of FAM-VAD FMK working solution for $1 \mathrm{~h}$ in a $\mathrm{CO}_{2}$ incubator. Fluorescence intensity was measured at the excitation wavelength of $490 \mathrm{~nm}$ and emission wavelength of $520 \mathrm{~nm}$ with Tecan Infinite ${ }^{\circledR}$ 200 PRO multimode microplate reader.

\subsection{Statistical Analysis}

Data were expressed as mean \pm standard deviation (SD) unless specified otherwise. Multiple comparisons were calculated by analysis of variance (ANOVA) with a TukeyKramer post-hoc test with data comparison among all groups. Data from two groups were analysed by Student's $t$ test. All statistical tests were performed using JMP Pro version 12.0.1 (SAS Institute, Cary, NC, USA). 


\section{Results}

\subsection{Phenotypic Switching of $\mathrm{CD} 4^{+} \mathrm{CD} 25^{+} \mathrm{FOXP} 3^{+} \mathrm{T}_{\text {reg }}$ Cells from $\mathrm{CD} 45 \mathrm{R} A^{+}$to $\mathrm{CD} 45 \mathrm{RO} \mathrm{O}^{+}$} during Development in Early Childhood

The surface marker expression of $\mathrm{CD} 4^{+} \mathrm{T}$ cells in paediatric subjects with or without allergy was determined by flow cytometric analysis. As shown in Figure 1a in a representative flow histogram, the majority of $\mathrm{CD} 4{ }^{+} \mathrm{CD} 25^{+} \mathrm{FOXP}^{+} \mathrm{T}$ cells from the control without allergy and subject with allergy (subject with allergy no. 1 in Figure 1a) expressed comparably low or no $\mathrm{CD} 127\left(\mathrm{CD} 127^{-/ \text {low }}\right)$. In addition, as shown in representative cases, the percentage of $\mathrm{CD}^{+}{ }^{+} \mathrm{CD} 25^{+} \mathrm{FOXP} 3^{+} \mathrm{T}$ cells that were $\mathrm{CD} 45 \mathrm{RO}^{+}$was lower in the 1-year-old control and the 1-year-old allergic subject no. 2 that had both food allergy and atopic dermatitis than that in the allergic subject no. 3, an 9.7-year-old child with paediatric allergic asthma (Figure 1b). In agreement with previous studies, FOXP3 expression was much higher in the $\mathrm{CD} 45 \mathrm{RO}^{+}$population than in the $\mathrm{CD}^{2} 5 \mathrm{RA}^{+}$population (Figure 1c) [11]. Furthermore, $\mathrm{CD} 45 \mathrm{RO}$ expression on $\mathrm{CD}^{+} \mathrm{CD} 25^{+} \mathrm{FOXP}^{+} \mathrm{T}$ cells was affected by age. Our analysis demonstrated decreases in CD45RA expression with reciprocal increases in the expression of CD45RO beginning at the age of 4 years (Figure 1d,e). However, the percentage of $\mathrm{CD} 45 \mathrm{RO}$ population in $\mathrm{CD} 4^{+} \mathrm{CD} 25^{+} \mathrm{FOXP}^{+} \mathrm{T}$ cells in the paediatric cohort did not reach the level reported in adults, which is $88.5 \pm 7.5 \%$ in $\mathrm{CD} 4{ }^{+} \mathrm{CD} 25^{\text {high }} \mathrm{T}$ cells and approximately $99 \%$ in $\mathrm{CD} 4^{+} \mathrm{CD} 25^{\text {very high }} \mathrm{T}$ cells $[11,28]$.

\section{a}
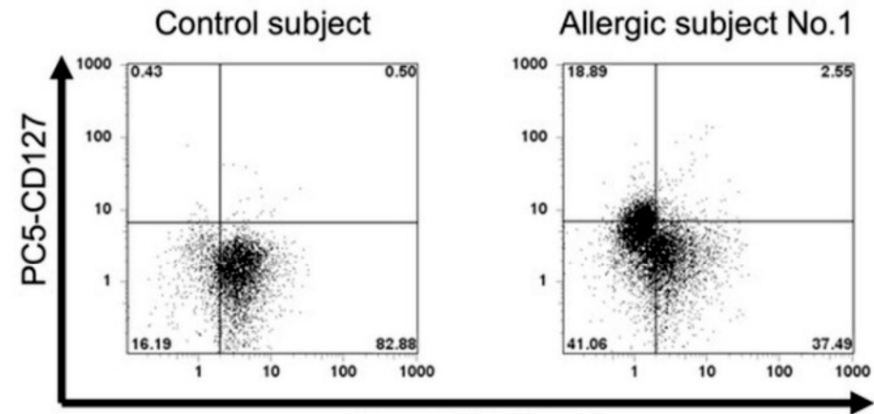

b

Alexa488-FOXP3

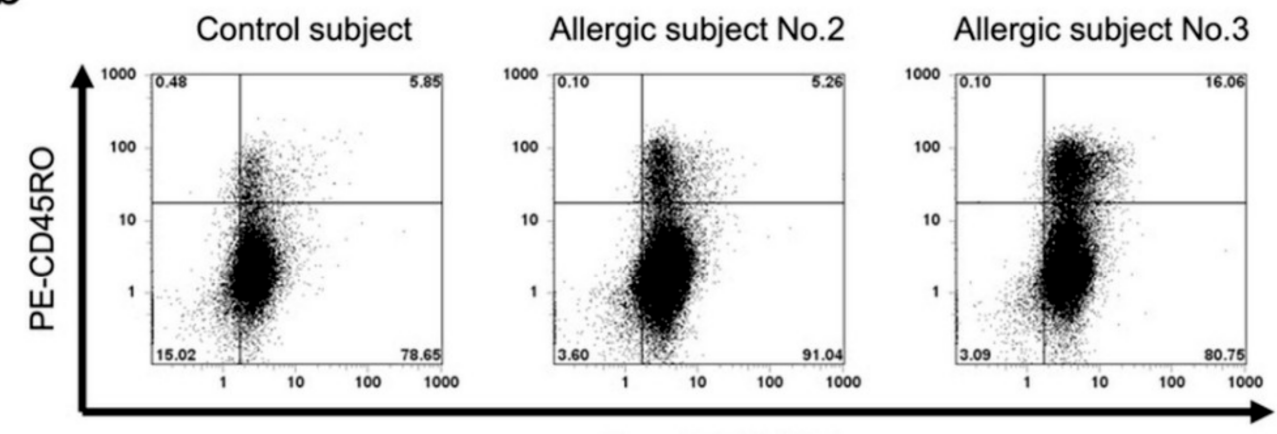

Alexa488-FOXP3

Figure 1. Cont. 
C

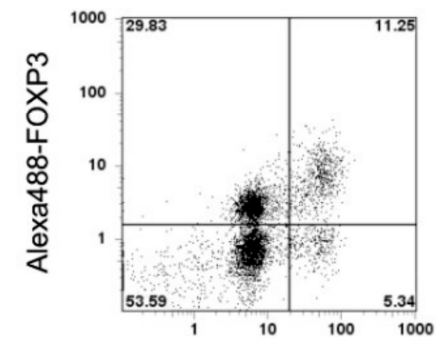

PE-CD45RO

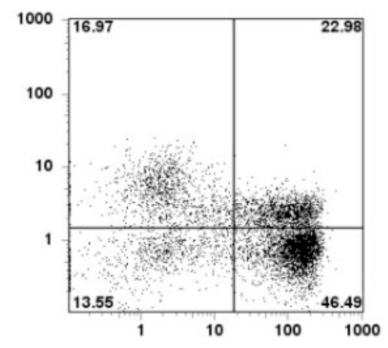

PE-CD45RA

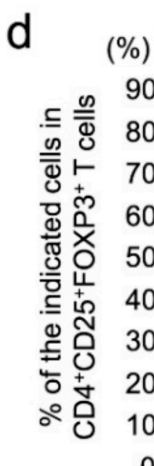

$\%)$

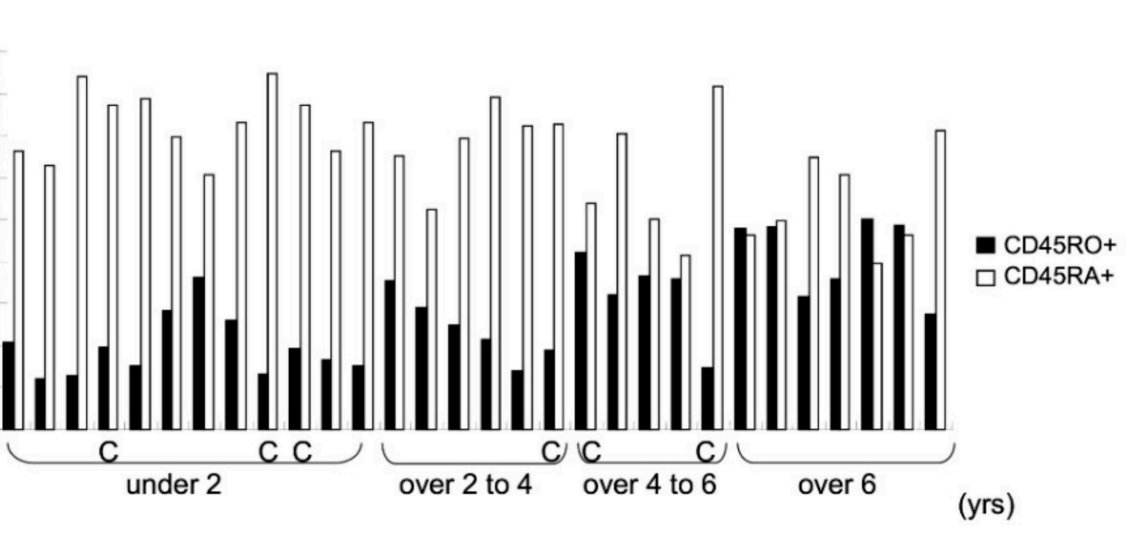

C; Non-allergic subject

e
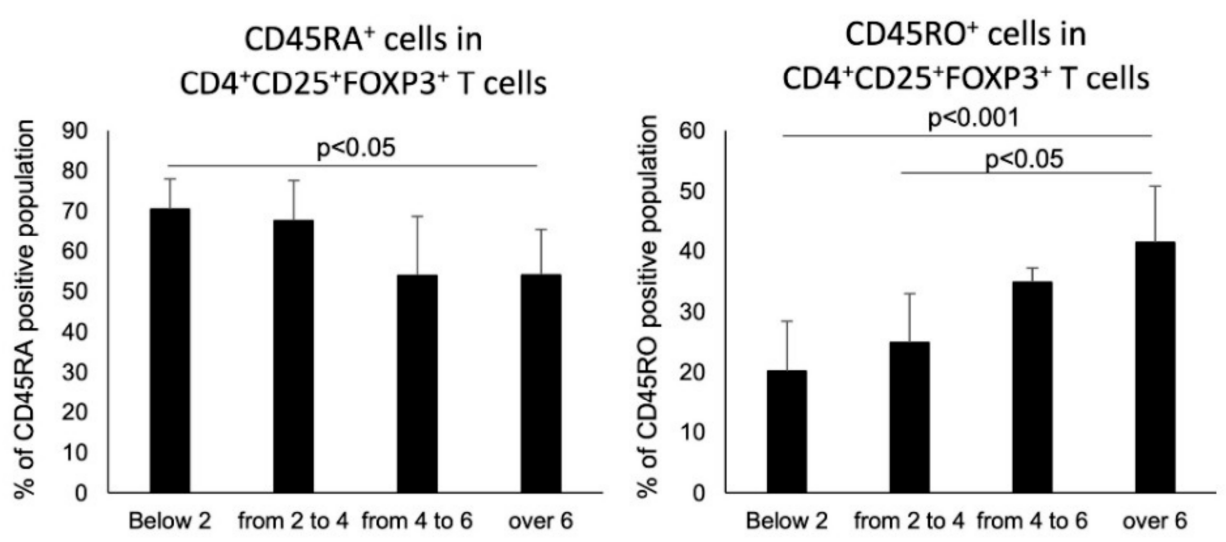

Figure 1. Flow cytometric surface marker analysis of $\mathrm{CD}^{+} \mathrm{T}$ cells isolated from paediatric PBMCs are shown from representative cases. In total, $1 \times 10^{6} \mathrm{CD}^{+}$cells were stained with Alexa 488FOXP3, PE-CD25, and PC5-CD127 (a), or with Alexa 488-FOXP3, PC5-CD25, and PE-CD45RO (b). Representative flow histograms are shown. (c) The cells were stained with Alexa 488-FOXP3, PC5-CD25, and PE-CD45RO or CD45RA. Representative flow histograms are shown. (d) Results from individual paediatric subjects are plotted by bar graph. (e) Data from (d) were combined into 4 groups by age, and the difference was statistically analysed. All histograms were gated with CD25 because of the analysis of purified $\mathrm{CD} 4^{+} \mathrm{T}$ cells.

\subsection{High Tolerance of $\mathrm{CD} 44^{+} \mathrm{CD} 25^{\text {high }} \mathrm{T}_{\text {reg }}$ Cells from Adults without Asthma to $\mathrm{H}_{2} \mathrm{O}_{2}$-Mediated Oxidative Stress}

Activation of ERK1/2 signalling by its phosphorylation (pERK1/2) in $\mathrm{T}_{\text {reg }}$ cells has been shown to be insensitive to T-cell receptor (TCR) stimulation and oxidative stress [29,30], whereas phosphorylation of p38 MAPK (pp38 MAPK) plays an important role in $\mathrm{T}$ cell activation [31,32]. Therefore, we analysed pERK1/2 and pp38 MAPK levels in $\mathrm{H}_{2} \mathrm{O}_{2}$-exposed $\mathrm{T}_{\text {regs }}$ from subjects with allergy. Our results indicated that $\mathrm{H}_{2} \mathrm{O}_{2}$ resulted in a dose-dependent phosphorylation of $\mathrm{p} 38 \mathrm{MAPK}$ in $\mathrm{CD} 4{ }^{+} \mathrm{CD} 25^{\text {high }} \mathrm{T}_{\text {regs }}$ from paediatric and adult subjects without allergy (Figure 2a). Further, $\mathrm{T}_{\text {regs }}$ from asthmatic adult 
subjects were more susceptible to p38 MAPK phosphorylation upon exposure to $50 \mu \mathrm{M}$ $\mathrm{H}_{2} \mathrm{O}_{2}$ than those from subjects without asthma. The responses of $\mathrm{CD} 4^{+} \mathrm{CD} 25^{\text {high }} \mathrm{T}_{\text {reg }}$ cells from paediatric subjects with or without allergy to $\mathrm{H}_{2} \mathrm{O}_{2}$ were similar to those observed in the same cell population from adult subjects with allergy (Figure $2 b, c)$. In contrast, ERK1/2 phosphorylation in $\mathrm{CD} 4^{+} \mathrm{CD} 25^{\text {high }} \mathrm{T}$ cells from adult subjects without asthma was observed only at high dose $\mathrm{H}_{2} \mathrm{O}_{2}(10 \mathrm{mM})$ treatment (Figure 3a). Measurement of $\left[\mathrm{Ca}^{2+}\right]_{\mathrm{i}}$ results in these adult subjects showed that pERK1/2 accumulation induced by $10 \mathrm{mM}$ $\mathrm{H}_{2} \mathrm{O}_{2}$ corresponded with increased influx of $\mathrm{Ca}^{2+}$, indicating the characteristic anergic response of these $\mathrm{T}_{\text {reg }}$ cells [12] (Figure $3 \mathrm{~b}-\mathrm{d}$ ). $\mathrm{CD} 4^{+} \mathrm{CD} 25^{\text {high }} \mathrm{T}_{\text {reg }}$ cells from subjects with increased $\mathrm{Ca}^{2+}$ response showed increased pERK1/2 expression, whereas cells with poor $\mathrm{Ca}^{2+}$ response were from subjects without asthma. However, the change in pERK1/2 expression in paediatric $\mathrm{CD} 4{ }^{+} \mathrm{CD} 25^{\text {high }} \mathrm{T}_{\text {regs }}$ cells was different compared with that observed in adults. ERK1/2 phosphorylation was observed at lower doses of $\mathrm{H}_{2} \mathrm{O}_{2}$ in $\mathrm{CD} 4^{+} \mathrm{CD} 25^{\text {high }}$ $\mathrm{T}_{\text {reg }}$ cells from paediatric subjects, and occurred more frequently, compared with adults. In addition, ERK1/2 phosphorylation was comparable between paediatric subjects with and without allergy (Figure 3b,c).

\subsection{Age-Dependent Sensitivity of Jurkat Tet-On ${ }^{\circledR}$ FOXP3 Cells to $\mathrm{H}_{2} \mathrm{O}_{2}$ Exposure In Vitro}

Jurkat cells inducibly overexpressing FOXP3 for 2 days (FOXP3 2-day cells) are similar to $\mathrm{CD} 4^{+} \mathrm{CD} 25^{+} \mathrm{CD} 127^{- \text {low }} \mathrm{T}$ cells from subjects without asthma and FOXP3 5-day cells are similar to $\mathrm{T}_{\text {regs }}$ from asthmatic subjects. Sensitivity to oxidative stress was evaluated by $\mathrm{H}_{2} \mathrm{O}_{2}$-induced caspase activity, intracellular glutathione content, and microarray analysis. The glutathione content of FOXP3 2-day cells was similar to that measured in control cells; however, it was decreased in FOXP3 5-day cells (Figure 4a). $\mathrm{H}_{2} \mathrm{O}_{2}$-induced caspase activation in FOXP3 2-day cells was lesser than that observed in control cells treated with $\mathrm{H}_{2} \mathrm{O}_{2}$; however, caspase activation in FOXP3 5-day cells was restored to the level measured in control cells (Figure 4b). Microarray analysis revealed that peroxiredoxin (PRDX)-2, -3, and -4 were among the antioxidant genes that were increased distinctly in FOXP3 2-day cells, but not in control or FOXP3 5-day cells (Table 2). The results obtained by microarray were confirmed by measurement of the mRNA expression of these three genes in $\mathrm{T}_{\text {reg }}$ cells isolated from peripheral blood of adult subjects with or without asthma (Figure 4c).

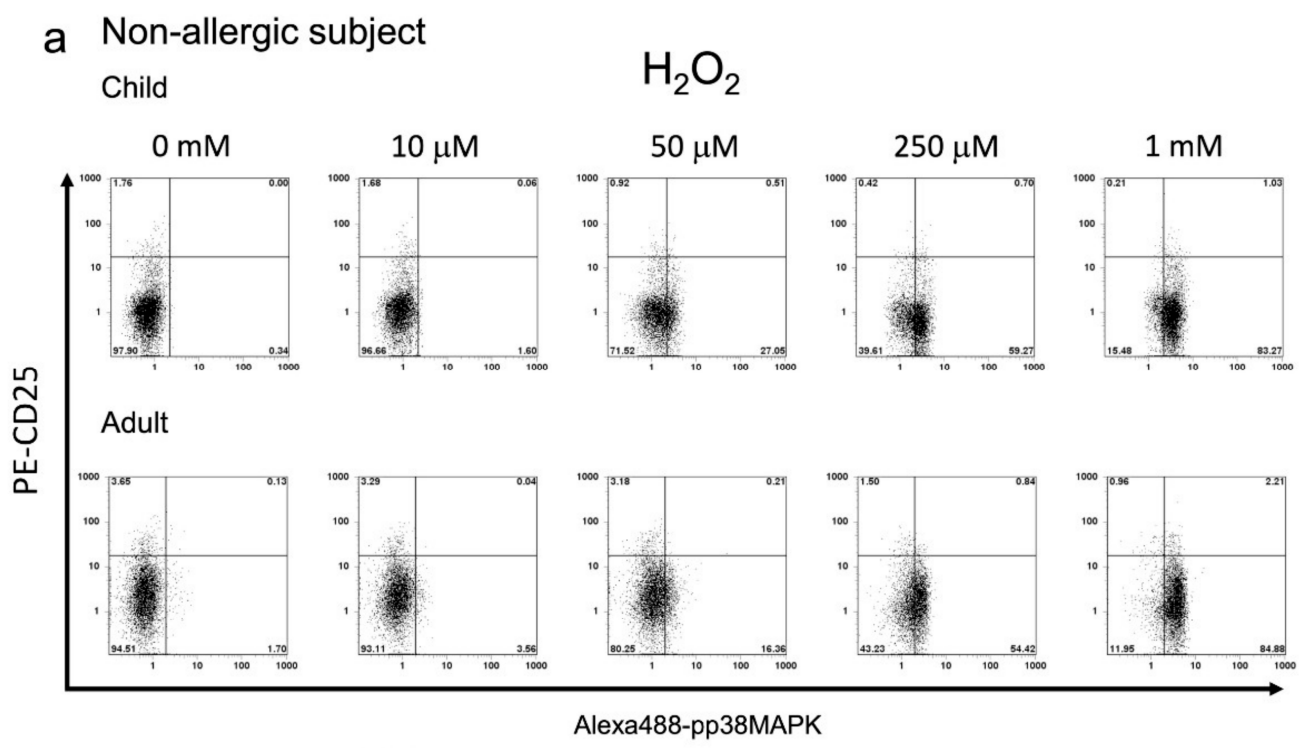

Figure 2. Cont. 


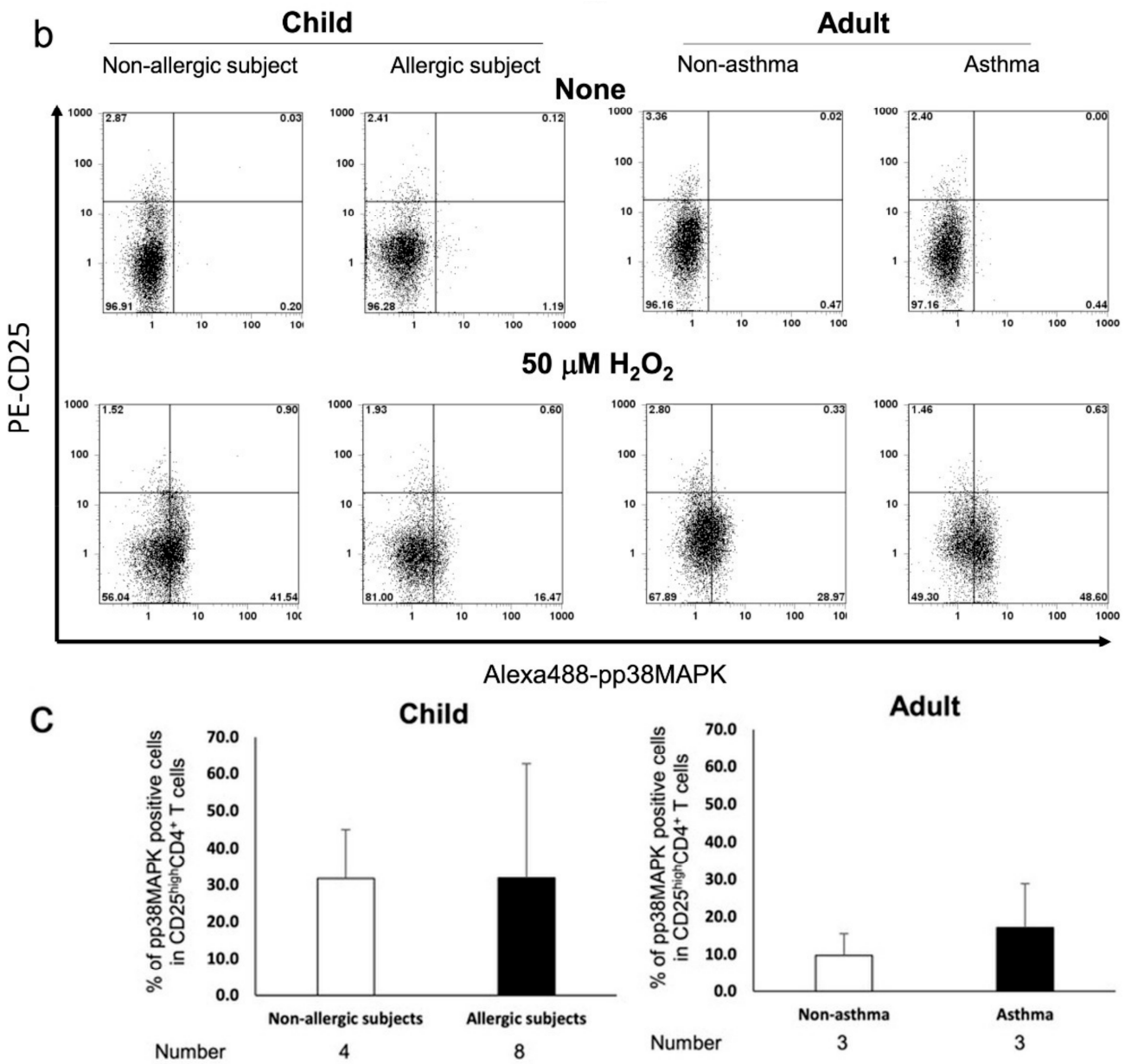

Figure 2. Flow cytometric measurement of p38 MAPK phosphorylation in response to $\mathrm{H}_{2} \mathrm{O}_{2}$ exposure in $\mathrm{CD}^{+} \mathrm{CD} 25^{\text {high }} \mathrm{T}$ cells from paediatric and adult subjects. $3 \times 10^{5}$ PBMCs were incubated for $10 \mathrm{~min}$ and stained with PC5-CD4, PE-CD25, and Alexa 488-pp38 MAPK. Representative flow histograms from paediatric subjects without allergy and adult subjects without asthma are shown (a). Phosphorylation of p38 MAPK in cells exposed to $50 \mu \mathrm{M} \mathrm{H}_{2} \mathrm{O}_{2}$ or vehicle were compared between paediatric subjects with and without allergy and adult subjects with or without asthma. Representative flow histograms (b) and average percentage of pp38 MAPK-positive cells are plotted by bar graphs (c). Gating was performed on cells highly expressing CD25 antigen.

a Non-allergic subject Child

$$
\mathrm{H}_{2} \mathrm{O}_{2}
$$
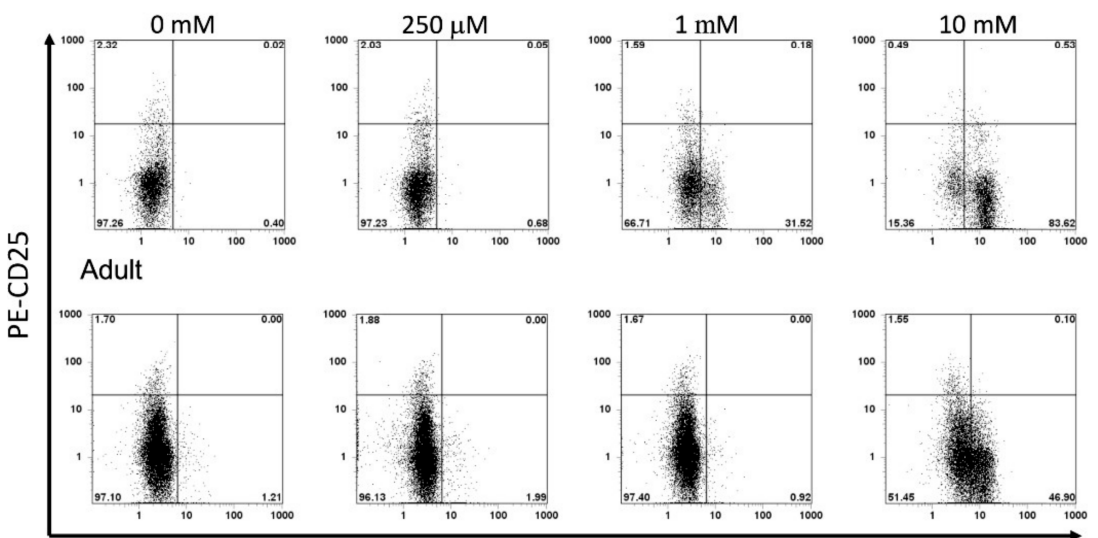

Alexa488-pERK

Figure 3. Cont. 


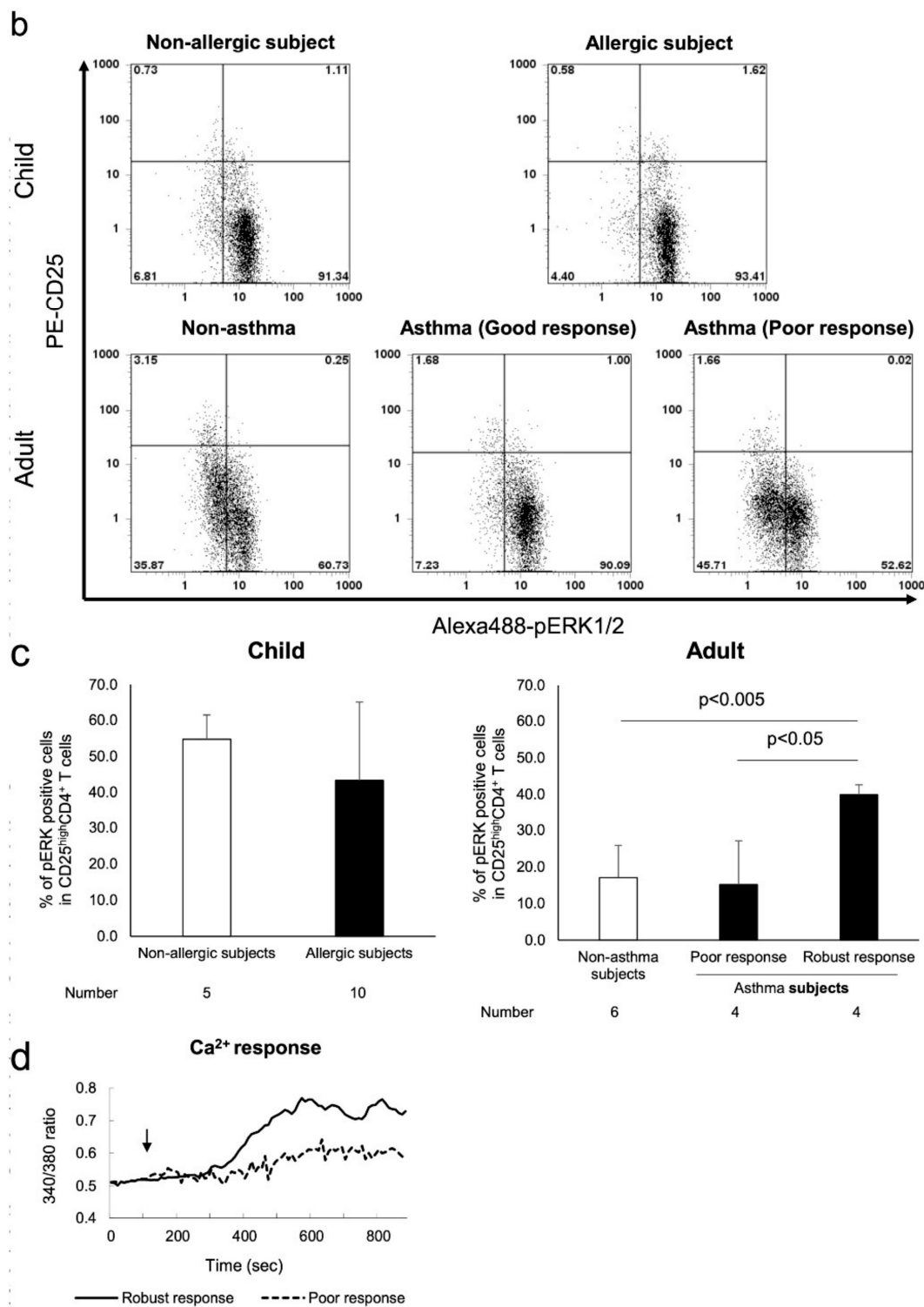

Figure 3. Flow cytometric measurement of ERK1/2 phosphorylation by $\mathrm{H}_{2} \mathrm{O}_{2}$ exposure in $\mathrm{CD} 4^{+} \mathrm{CD} 25^{\text {high }} \mathrm{T}$ cells from paediatric subjects without allergy and adult subjects without asthma that were exposed to $10 \mathrm{mM} \mathrm{H}_{2} \mathrm{O}_{2}$ were stained with PC5-CD4, PE-CD25, and Alexa 488-pERK1/2. The representative flow histograms are shown in (a). The typical patterns of pERK $1 / 2$ expression among all child subject groups are shown in (b). The average percentage of $\mathrm{pERK} 1 / 2$ - positive cells in all adult subject groups were plotted by bar graphs, and asthma subjects were further divided into two groups by $\mathrm{Ca}^{2+}$ response (c). Typical patterns (poor response and robust response) of $\mathrm{Ca}^{2+}$ response are depicted in (d). Gating was performed on cells highly expressing CD25 antigen. 
a

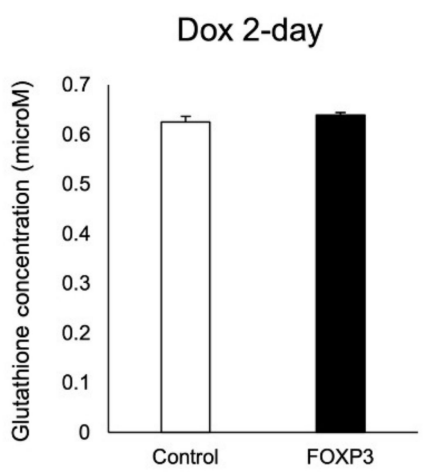

b

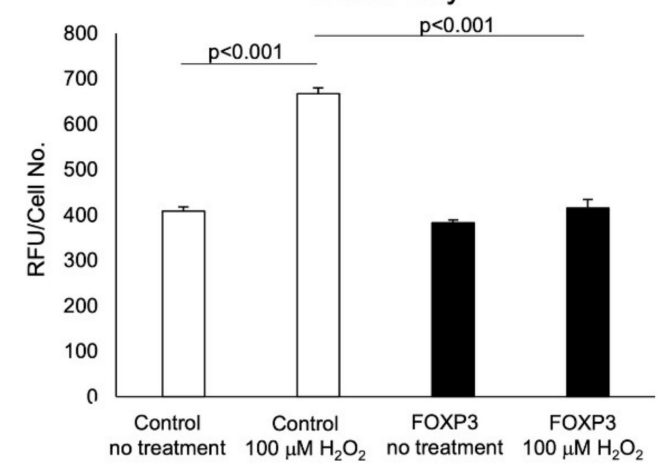

C

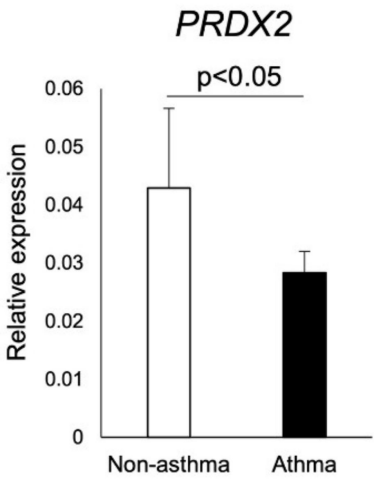

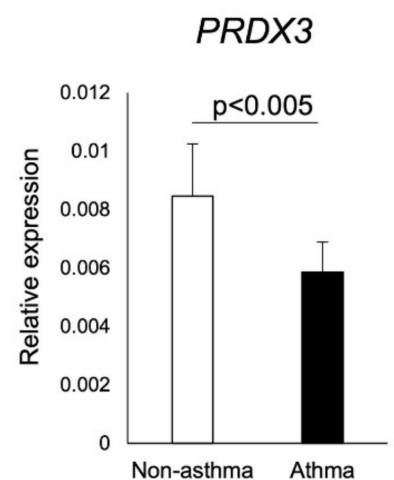

PRDX3
Dox 5-day

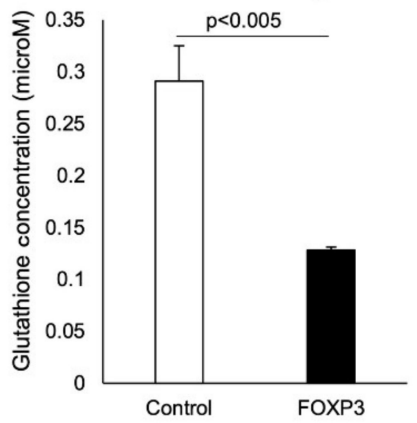

Dox 5-day

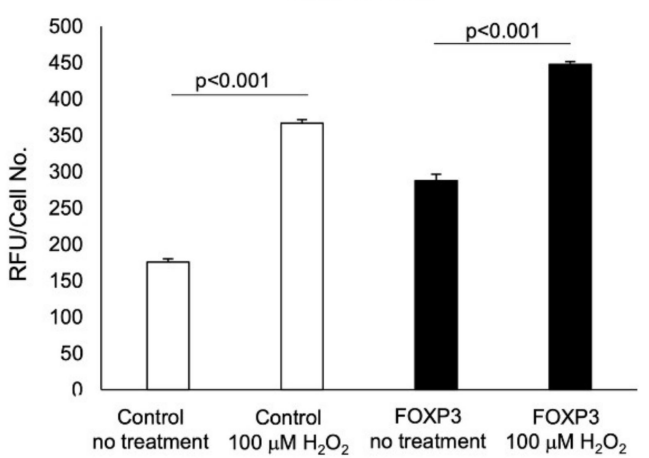
PRDX4

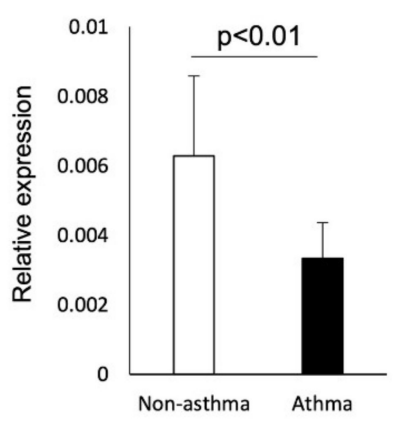

Figure 4. Assessment of the sensitivity of $\mathrm{FOXP3}^{+}$cells to oxidative stress. The measurement of antioxidant levels and caspase activity in response to $\mathrm{H}_{2} \mathrm{O}_{2}$ were compared with those in control cells. Glutathione content in FOXP3 2-day and FOXP3 5-day cells were compared with control cells (a). Caspase activity in response in the abovementioned cells exposed to $100 \mu \mathrm{M} \mathrm{H}_{2} \mathrm{O}_{2}$ for $4 \mathrm{~h}$ were measured $(\mathbf{b})$. mRNA expression of peroxiredoxins in $\mathrm{CD} 4{ }^{+} \mathrm{CD} 25^{+} \mathrm{CD} 127^{-/ \text {low }} \mathrm{T}$ cells were quantified by real-time PCR (c).

Table 2. Microarray analysis.

\begin{tabular}{|c|c|c|c|c|c|c|}
\hline \multirow[b]{2}{*}{ Symbol } & \multirow[b]{2}{*}{ Description } & \multicolumn{2}{|c|}{ Control } & \multicolumn{2}{|c|}{ FOXP3 } & \multirow{2}{*}{$\frac{\text { Ratio }}{\text { (FOXP3/Control 2-Day) }}$} \\
\hline & & 2-Day & 5-Day & 2-Day & 5-Day & \\
\hline PXDN & $\begin{array}{l}\text { Peroxidasin homolog Precursor (EC 1.11.1.7)(Vascular } \\
\text { peroxidase 1)(Melanoma-associated antigen } \\
\text { MG50)(p53-responsive gene } 2 \text { protein) } \\
\text { [Source:UniProtKB/Swiss-Prot;Acc:Q92626] }\end{array}$ & 69 & 50 & 230 & 184 & 3.33 \\
\hline TXNIP & $\begin{array}{l}\text { Thioredoxin-interacting protein (Vitamin D3 } \\
\text { up-regulated protein 1)(Thioredoxin-binding protein 2) } \\
\text { [Source:UniProtKB/Swiss-Prot;Acc:Q9H3M7] }\end{array}$ & 55 & 29 & 140 & 54 & 2.55 \\
\hline
\end{tabular}


Table 2. Cont

\begin{tabular}{|c|c|c|c|c|c|c|}
\hline \multirow[b]{2}{*}{ Symbol } & \multirow[b]{2}{*}{ Description } & \multicolumn{2}{|c|}{ Control } & \multicolumn{2}{|c|}{ FOXP3 } & \multirow{2}{*}{$\frac{\text { Ratio }}{\text { (FOXP3/Control 2-Day) }}$} \\
\hline & & 2-Day & 5-Day & 2-Day & 5-Day & \\
\hline PRDX4 & $\begin{array}{l}\text { Peroxiredoxin-4 (EC 1.11.1.15)(Prx-IV)(Thioredoxin } \\
\text { peroxidase AO372)(Thioredoxin- dependent peroxide } \\
\text { reductase A0372)(Antioxidant enzyme } \\
\text { AOE372)(AOE37-2) } \\
\text { [Source:UniProtKB/Swiss-Prot;Acc:Q13162] }\end{array}$ & 392 & 392 & 621 & 459 & 1.58 \\
\hline GPX4 & $\begin{array}{l}\text { Phospholipid hydroperoxide glutathione peroxidase, } \\
\text { mitochondrial Precursor (PHGPx)(EC 1.11.1.12)(GPX-4) } \\
\text { [Source:UniProtKB/Swiss-Prot;Acc:P36969] }\end{array}$ & 1444 & 1151 & 2233 & 1832 & 1.55 \\
\hline SRXN1 & $\begin{array}{l}\text { Sulfiredoxin-1 (EC 1.8.98.2) } \\
\text { [Source:UniProtKB/Swiss-Prot;Acc:Q9BYN0] }\end{array}$ & 127 & 93 & 181 & 108 & 1.43 \\
\hline PRDX3 & $\begin{array}{l}\text { Thioredoxin-dependent peroxide reductase, } \\
\text { mitochondrial Precursor (EC } \\
\text { 1.11.1.15)(Peroxiredoxin-3)(PRX III)(Antioxidant } \\
\text { protein 1)(AOP-1)(Protein MER5 homolog)(HBC189) } \\
\text { [Source:UniProtKB/Swiss-Prot;Acc:P30048] }\end{array}$ & 550 & 555 & 767 & 550 & 1.39 \\
\hline PRDX2 & $\begin{array}{l}\text { Peroxiredoxin-2 (EC 1.11.1.15)(Thioredoxin peroxidase } \\
\text { 1)(Thioredoxin-dependent peroxide reductase } \\
\text { 1)(Thiol-specific antioxidant } \\
\text { protein)(TSA)(PRP)(Natural killer cell-enhancing factor } \\
\text { B)(NKEF-B) } \\
\text { [Source:UniProtKB/Swiss-Prot;Acc:P32119] }\end{array}$ & 1972 & 1919 & 2378 & 1756 & 1.21 \\
\hline PRDX5 & $\begin{array}{l}\text { Peroxiredoxin-5, mitochondrial Precursor (EC } \\
\text { 1.11.1.15)(Prx-V)(Peroxisomal antioxidant } \\
\text { enzyme)(PLP)(Thioredoxin reductase)(Thioredoxin } \\
\text { peroxidase PMP20)(Antioxidant enzyme } \\
\text { B166)(AOEB166)(TPx type VI)(Liver tissue 2D-page } \\
\text { spot 71B)(Alu corepressor 1) } \\
\text { [Source:UniProtKB/Swiss-Prot;Acc:P30044] }\end{array}$ & 1571 & 1910 & 1529 & 1978 & 0.97 \\
\hline $\mathrm{TXN}$ & $\begin{array}{l}\text { Thioredoxin } \\
\text { (Trx)(ATL-derivedfactor)(ADF)(Surface-associated } \\
\text { sulphydryl protein)(SASP) [Source:UniProtKB/Swiss- } \\
\text { Prot;Acc:P10599] }\end{array}$ & 3510 & 3689 & 2338 & 1850 & 0.67 \\
\hline PRDX1 & $\begin{array}{l}\text { Peroxiredoxin-1 (EC 1.11.1.15)(Thioredoxin peroxidase } \\
\text { 2)(Thioredoxin-dependent peroxide reductase } \\
\text { 2)(Proliferation-associated gene protein)(PAG)(Natural } \\
\text { killer cell-enhancing factor A)(NKEF-A) } \\
\text { [Source:UniProtKB/Swiss- Prot;Acc:Q06830] }\end{array}$ & 3861 & 3068 & 1303 & 1138 & 0.34 \\
\hline
\end{tabular}

Shading shows increased gene expression in FOXP3 2-day cells compared with the others.

\section{Discussion}

CD45RO, as a $\mathrm{T}_{\text {reg }}$ surface marker, is considered an indicator of $\mathrm{T}_{\text {reg }}$ maturity. $\mathrm{CD}^{+} \mathrm{FOXP}{ }^{\text {low }} \mathrm{CD} 45 \mathrm{RA}^{+} \mathrm{T}$ cells are naive resting $\mathrm{T}_{\text {reg }}$ cells, whereas $\mathrm{CD}^{+}{ }^{+} \mathrm{FOXP} 3{ }^{\text {high }} \mathrm{CD} 45 \mathrm{RA}^{-}$ $\mathrm{T}$ cells, like $\mathrm{CD} 4^{+} \mathrm{FOXP} 3{ }^{\text {high }} \mathrm{CD} 45 \mathrm{RO}^{+} \mathrm{T}$ cells, constitute mature activated $\mathrm{T}_{\text {reg }}$ cells [23]. Both $\mathrm{T}_{\text {reg }}$ subtypes have a suppressive capacity in vitro, whereas phenotypically immature $\mathrm{T}_{\text {regs }}$ have the capacity to differentiate into phenotypically mature $\mathrm{T}_{\text {reg }}$ cells in vitro and in vivo. Previous reports indicated that phenotypically immature $T_{\text {regs }}$ predominated in cord blood and in newborns $[21,33]$. Our data suggested that CD4 ${ }^{+}$FOXP3 ${ }^{\text {low }}{ }^{2}$ D45RA ${ }^{+}$ $T$ cells were dominant in peripheral blood before the age of 4 years, and that $\mathrm{T}_{\text {regs }}$ subsequently switched from an immature phenotype to a mature phenotype. Maternal antigen exposure is a crucial factor in phenotypic switching of CD45 T cell isoforms from pregnancy to infancy. Thereafter, phenotypic switching persists on further extrinsic antigen exposure that continues until adolescence. Similarly, $\mathrm{T}_{\text {reg }}$ cells have been suggested to undergo this type of conversion from immature to mature phenotypes in adults.

Several studies implicate low FOXP3 protein expression as a mechanism for abnormal $\mathrm{T}_{\text {reg }}$ function [6-9]. When we compared the characteristics of $\mathrm{T}_{\text {reg }}$ cells between paediatric and adult subjects with or without allergy, we observed that the phosphorylation of 
cellular signalling molecules ERK1/2 and p38 MAPK in T cells were increased by exposure to $\mathrm{H}_{2} \mathrm{O}_{2}$. Recently, $\mathrm{T}_{\text {reg }}$ cells were reported to have a high oxidative stress buffering capacity via increased secretion of thioredoxin- 1 (TXN) [24]. When we examined $\mathrm{T}_{\text {reg }}$ cells with functional assays, we specifically observed that the $\mathrm{T}_{\text {reg }}$ cells from adults without asthma had attenuated pERK1/2 accumulation in response to $\mathrm{H}_{2} \mathrm{O}_{2}$ treatment, whereas the $T_{\text {reg }}$ cells from adults with asthma were able to increase $\mathrm{pERK} 1 / 2$ under the same conditions. In addition, pERK1/2 was associated with robust $\mathrm{Ca}^{2+}$ influx in response to TCR stimulation in $\mathrm{T}_{\text {reg }}$ cells from adults with asthma. Previous reports demonstrated that the $\mathrm{Ca}^{2+}$ response of $\mathrm{T}_{\text {reg }}$ cells from children was correlated with the severity of asthma [11] and that of $\mathrm{T}_{\text {reg }}$ cells from adults was correlated with functional abnormalities of this cell type [12]. The $\mathrm{Ca}^{2+}$ response of adult $\mathrm{T}_{\text {reg }}$ cells can be divided into poor and robust response. Our findings indicated that robust $\mathrm{pERK} 1 / 2$ accumulation in $\mathrm{T}_{\text {reg }}$ cells from adults with asthma correlated with robust $\mathrm{Ca}^{2+}$ responses. Several studies suggested that ERK1/2 phosphorylation may occur following intracellular $\mathrm{Ca}^{2+}$ influx induced by exposure to $\mathrm{H}_{2} \mathrm{O}_{2}[27,34]$ and imply that robust $\mathrm{Ca}^{2+}$ response in $\mathrm{T}_{\text {reg }}$ cells may stimulate ERK1/2 phosphorylation. The increases in $\mathrm{pERK} 1 / 2$ and pp38 MAPK expression in response to oxidative stress were more robust in $\mathrm{T}_{\text {reg }}$ cells from paediatric subjects than those from adult subjects. These results imply that immature CD45RA ${ }^{+} \mathrm{T}_{\text {reg }}$ cells were more sensitive to oxidative stress than $\mathrm{CD} 45 \mathrm{RO}^{+}$mature $\mathrm{T}_{\text {reg }}$ cells.

Our caspase activity studies showed that FOXP3 2-day cells were more tolerant to $\mathrm{H}_{2} \mathrm{O}_{2}$ than control cells, despite comparable glutathione content in both cell types, suggesting a distinct antioxidant response against oxidative stress. Microarray analysis revealed that peroxiredoxins, but not thioredoxin-1, were involved in tolerance to oxidative stress in our model system. In agreement with the results of microarray analysis of Tet-On ${ }^{\circledR}$ Jurkat cells, mRNA expression of peroxiredoxin (PRDX)-2, -3 , and -4 in $\mathrm{T}_{\text {reg }}$ cells from adults with asthma was decreased compared with $\mathrm{T}_{\text {reg }}$ cells from adults without asthma. Similarly, in Th17 cells, peroxiredoxin-2 was suggested to function as an antioxidant during chronic inflammatory processes [35]. We speculate that $\mathrm{T}_{\text {reg }}$ cells from adults with asthma were sensitized by oxidative stress with regard to inflammation; thus, the activation of ERK1/2 signalling was easily transduced. Chronic exposure to oxidative stress has been suggested to lead to death of $\mathrm{T}_{\text {reg }}$ cells in adults with asthma, compared with those in adults without asthma. The $\mathrm{T}_{\text {reg }}$ cells from paediatric subjects were sensitive to $\mathrm{H}_{2} \mathrm{O}_{2}$ exposure and $\mathrm{Ca}^{2+}$-responsive to TCR stimulation, irrespective of the presence of allergies in subjects [11], suggesting that $T_{\text {reg }}$ cells from paediatric subjects were activated easily and were more susceptible to cell death. In summary, the phenotypic switching of $\mathrm{T}_{\text {reg }}$ cells were analysed based on the expression of CD45 isoforms during development. The high percentage of CD45RA ${ }^{+} \mathrm{T}_{\text {reg }}$ cells in paediatric subjects may be reflected in their increased ERK1/2 signalling in response to $\mathrm{H}_{2} \mathrm{O}_{2}$ exposure. In contrast, $\mathrm{T}_{\text {regs }}$ from adults without asthma, most of which expressed $\mathrm{CD} 45 \mathrm{RO}^{+}$, were tolerant to $\mathrm{H}_{2} \mathrm{O}_{2}$ exposure, whereas $\mathrm{T}_{\text {reg }}$ cells from adults with asthma were not. Increased tolerance of non-asthmatic adult $\mathrm{T}_{\text {reg }}$ cells may be attributable to intact upregulation of peroxiredoxins. Finally, assessment of MAPK phosphorylation in response to oxidative stress by flow cytometry is a simple and effective method for the evaluation of $\mathrm{T}_{\text {reg }}$ cell function in adults with asthma.

\section{Conclusions}

Developmental $\mathrm{T}_{\text {reg }}$ phenotypic switching occurs in early childhood, which may be a consequence of exposure to extrinsic antigens such as bacteria and viruses. The differential $\mathrm{T}_{\text {reg }}$ sensitivity to oxidative stress observed in children and adults was likely dependent on phenotypic CD45 isoform switching. Increased sensitivity of $\mathrm{T}_{\text {reg }}$ cells from adults with asthma to $\mathrm{H}_{2} \mathrm{O}_{2}$ resulted from a reduction of peroxiredoxin- $2,-3$, and -4 and increased pERK1/2 via impaired $\mathrm{Ca}^{2+}$ response in these cells.

Supplementary Materials: The following are available online at https://www.mdpi.com/article/10 .3390/biomedicines9060616/s1: Figure S1: Microarray data. 
Author Contributions: Conceptualization, Y.Y. and T.N.; methodology, Y.Y., T.N., R.T. and Y.N. (Yoichi Negishi).; validation, Y.Y.; formal analysis, Y.Y.; investigation, Y.Y., T.N., R.T., M.N. and A.H.; resources, Y.Y., Y.N. (Yoichi Negishi) and Y.N. (Yasuko Nakano).; data curation, Y.Y. and A.H.; writing—original draft preparation, Y.Y.; writing—review and editing, T.N., R.T., Y.N. (Yoichi Negishi). and Y.N. (Yasuko Nakano); visualization, Y.Y. and R.T.; supervision, Y.Y., Y.N. (Yoichi Negishi) and Y.N. (Yasuko Nakano); project administration, Y.Y.; funding acquisition, T.N., Y.N. (Yoichi Negishi) and Y.N. (Yasuko Nakano). All authors have read and agreed to the published version of the manuscript.

Funding: This work was supported in part by a Grant-in-Aid from the Ministry of Education, Culture, Sports, Science, and Technology of Japan (\#24591471 and \#15K09557).

Institutional Review Board Statement: The study was conducted according to the guidelines of the Declaration of Helsinki and approved by the Showa University Medical Ethics Committee (protocol number 310 for paediatric subjects, protocol number 2002022 for adult subjects) and the Tokyo Metropolitan Ebara Hospital Trust local research and ethics committee.

Informed Consent Statement: Informed consent was obtained from all subjects involved in the study. Written informed consent has been obtained from the patient(s) to publish this paper.

Data Availability Statement: Data are contained within the article or Supplementary Materials.

Acknowledgments: We thank Akiko Wakagi, who is a student in the Showa University School of Pharmacy, for technical assistance.

Conflicts of Interest: The authors declare no conflict of interest.

\section{References}

1. Akdis, M.; Verhagen, J.; Taylor, A.; Karamloo, F.; Karagiannidis, C.; Crameri, R.; Thunberg, S.; Deniz, G.; Valenta, R.; Fiebig, H.; et al. Immune Responses in Healthy and Allergic Individuals Are Characterized by a Fine Balance between Allergen-Specific T Regulatory 1 and T Helper 2 Cells. J. Exp. Med. 2004, 199, 1567-1575. [CrossRef] [PubMed]

2. Jaffar, Z.; Ferrini, M.E.; Girtsman, T.A.; Roberts, K. Antigen-specific $\mathrm{T}_{\text {reg }}$ Regulate Th17-mediated Lung Neutrophilic Inflammation, B-cell Recruitment and Polymeric IgA and IgM Levels in the Airways. Eur. J. Immunol. 2009, 39, 3307-3314. [CrossRef] [PubMed]

3. Wing, K.; Onishi, Y.; Prieto-Martin, P.; Yamaguchi, T.; Miyara, M.; Fehervari, Z.; Nomura, T.; Sakaguchi, S. CTLA-4 Control over Foxp3+ Regulatory T Cell Function. Science 2008, 322, 271-275. [CrossRef]

4. Strickland, D.H.; Holt, P.G. T Regulatory Cells in Childhood Asthma. Trends Immunol. 2011, 32, 420-427. [CrossRef]

5. Hamasaki, Y.; Kohno, Y.; Ebisawa, M.; Kondo, N.; Nishima, S.; Nishimuta, T.; Morikawa, A. Japanese Guideline for Childhood Asthma 2014. Allergol. Int. 2014, 63, 335-356. [CrossRef]

6. Hartl, D.; Koller, B.; Mehlhorn, A.T.; Reinhardt, D.; Nicolai, T.; Schendel, D.J.; Griese, M.; Krauss-Etschmann, S. Quantitative and Functional Impairment of Pulmonary CD4 ${ }^{+} \mathrm{CD} 25^{\text {hi }}$ Regulatory T Cells in Pediatric Asthma. J. Allergy Clin. Immun. 2007, 119, 1258-1266. [CrossRef]

7. Provoost, S.; Maes, T.; Durme, Y.M.V.; Gevaert, P.; Bachert, C.; Schmidt-Weber, C.B.; Brusselle, G.G.; Joos, G.F.; Tournoy, K.G. Decreased FOXP3 Protein Expression in Patients with Asthma. Allergy 2009, 64, 1539-1546. [CrossRef] [PubMed]

8. Lin, Y.-L.; Shieh, C.-C.; Wang, J.-Y. The Functional Insufficiency of Human CD4 ${ }^{+}$CD25 high T-regulatory Cells in Allergic Asthma Is Subjected to TNF- $\alpha$ Modulation. Allergy 2008, 63, 67-74. [CrossRef] [PubMed]

9. Vale-Pereira, S.; Todo-Bom, A.; Geraldes, L.; Schmidt-Weber, C.; Akdis, C.A.; Mota-Pinto, A. FoxP3, GATA-3 and T-bet Expression in Elderly Asthma. Clin. Exp. Allergy 2011, 41, 490-496. [CrossRef]

10. Ling, E.M.; Smith, T.; Nguyen, X.D.; Pridgeon, C.; Dallman, M.; Arbery, J.; Carr, V.A.; Robinson, D.S. Relation of CD4 ${ }^{+}$CD25 ${ }^{+}$ Regulatory T-Cell Suppression of Allergen-Driven T-Cell Activation to Atopic Status and Expression of Allergic Disease. Lancet 2004, 363, 608-615. [CrossRef]

11. Yamamoto, Y.; Negoro, T.; Hoshi, A.; Wakagi, A.; Shimizu, S.; Banham, A.H.; Ishii, M.; Akiyama, H.; Kiuchi, Y.; Sunaga, S.; et al. Impaired $\mathrm{Ca}^{2+}$ Regulation of $\mathrm{CD}^{+} \mathrm{CD} 25^{+}$Regulatory T Cells from Pediatric Asthma. Int. Arch. Allergy Immunol. 2011, 156, 148-158. [CrossRef]

12. Negoro, T.; Shimizu, S.; Narushima, M.; Banham, A.H.; Wakabayashi, H.; Takayanagi, R.; Hagiwara, T.; Roncador, G.; Osabe, T.; Yanai, T.; et al. Elevated Receptor for Activated C Kinase 1 Expression Is Involved in Intracellular $\mathrm{Ca}^{2+}$ Influx and Potentially Associated with Compromised Regulatory T Cell Function in Patients with Asthma. Clin. Exp. Allergy 2014, 44, 1154-1169. [CrossRef]

13. Shi, H.-Z.; Li, S.; Xie, Z.-F.; Qin, X.-J.; Qin, X.; Zhong, X.-N. Regulatory CD4 ${ }^{+}$CD25 $5^{+}$T Lymphocytes in Peripheral Blood from Patients with Atopic Asthma. Clin. Immunol. 2004, 113, 172-178. [CrossRef] [PubMed]

14. Smyth, L.J.C.; Eustace, A.; Kolsum, U.; Blaikely, J.; Singh, D. Increased Airway T Regulatory Cells in Asthmatic Subjects. Chest 2010, 138, 905-912. [CrossRef] 
15. Thunberg, S.; Gafvelin, G.; Nord, M.; Grönneberg, R.; Grunewald, J.; Eklund, A.; Hage, M.V. Allergen Provocation Increases TH2-cytokines and FOXP3 Expression in the Asthmatic Lung. Allergy 2010, 65, 311-318. [CrossRef] [PubMed]

16. Karagiannidis, C.; Akdis, M.; Holopainen, P.; Woolley, N.J.; Hense, G.; Rückert, B.; Mantel, P.-Y.; Menz, G.; Akdis, C.A.; Blaser, K.; et al. Glucocorticoids Upregulate FOXP3 Expression and Regulatory T Cells in Asthma. J. Allergy Clin. Immun. 2004, 114, 1425-1433. [CrossRef] [PubMed]

17. Prado, C.; Gómez, J.; López, P.; de Paz, B.; Gutiérrez, C.; Suárez, A. Dexamethasone Upregulates FOXP3 Expression without Increasing Regulatory Activity. Immunobiology 2011, 216, 386-392. [CrossRef] [PubMed]

18. Robinson, D.S. Regulatory T Cells and Asthma. Clin. Exp. Allergy 2009, 39, 1314-1323. [CrossRef]

19. Ray, A.; Khare, A.; Krishnamoorthy, N.; Qi, Z.; Ray, P. Regulatory T Cells in Many Flavors Control Asthma. Mucosal. Immunol. 2010, 3, 216-229. [CrossRef]

20. Palomares, O.; Yaman, G.; Azkur, A.K.; Akkoc, T.; Akdis, M.; Akdis, C.A. Role of $\mathrm{T}_{\text {reg }}$ in Immune Regulation of Allergic Diseases. Eur. J. Immunol. 2010, 40, 1232-1240. [CrossRef]

21. Thornton, C.A.; Upham, J.W.; Wikström, M.E.; Holt, B.J.; White, G.P.; Sharp, M.J.; Sly, P.D.; Holt, P.G. Functional Maturation of $\mathrm{CD}^{+}{ }^{+} \mathrm{CD} 25^{+} \mathrm{CTLA}^{+}{ }^{+} \mathrm{CD} 45 \mathrm{RA}{ }^{+} \mathrm{T}$ Regulatory Cells in Human Neonatal T Cell Responses to Environmental Antigens/Allergens. J. Immunol. 2004, 173, 3084-3092. [CrossRef] [PubMed]

22. Valmori, D.; Merlo, A.; Souleimanian, N.E.; Hesdorffer, C.S.; Ayyoub, M. A Peripheral Circulating Compartment of Natural

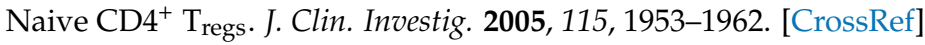

23. Miyara, M.; Yoshioka, Y.; Kitoh, A.; Shima, T.; Wing, K.; Niwa, A.; Parizot, C.; Taflin, C.; Heike, T.; Valeyre, D.; et al. Functional Delineation and Differentiation Dynamics of Human CD4 ${ }^{+}$T Cells Expressing the FoxP3 Transcription Factor. Immunity 2009, 30, 899-911. [CrossRef]

24. Mougiakakos, D.; Johansson, C.C.; Jitschin, R.; Böttcher, M.; Kiessling, R. Increased Thioredoxin-1 Production in Human Naturally Occurring Regulatory T Cells Confers Enhanced Tolerance to Oxidative Stress. Blood 2011, 117, 857-861. [CrossRef]

25. Baty, J.W.; Hampton, M.B.; Winterbourn, C.C. Proteomic Detection of Hydrogen Peroxide-Sensitive Thiol Proteins in Jurkat Cells. Biochem. J. 2005, 389, 785-795. [CrossRef] [PubMed]

26. Roncador, G.; Brown, P.J.; Maestre, L.; Hue, S.; Martínez-Torrecuadrada, J.L.; Ling, K.; Pratap, S.; Toms, C.; Fox, B.C.; Cerundolo, V.; et al. Analysis of FOXP3 Protein Expression in Human CD4 ${ }^{+} \mathrm{CD} 25^{+}$Regulatory T Cells at the Single-cell Level. Eur. J. Immunol. 2005, 35, 1681-1691. [CrossRef] [PubMed]

27. Yamamoto, S.; Shimizu, S.; Kiyonaka, S.; Takahashi, N.; Wajima, T.; Hara, Y.; Negoro, T.; Hiroi, T.; Kiuchi, Y.; Okada, T.; et al. TRPM2-Mediated $\mathrm{Ca}^{2+}$ Influx Induces Chemokine Production in Monocytes That Aggravates Inflammatory Neutrophil Infiltration. Nat. Med. 2008, 14, 738-747. [CrossRef] [PubMed]

28. Baecher-Allan, C.; Brown, J.A.; Freeman, G.J.; Hafler, D.A. CD4 ${ }^{+}$CD25 $5^{\text {high }}$ Regulatory Cells in Human Peripheral Blood. J. Immunol. 2001, 167, 1245-1253. [CrossRef]

29. Chang, C.-F.; D'Souza, W.N.; Ch'en, I.L.; Pages, G.; Pouyssegur, J.; Hedrick, S.M. Polar Opposites: Erk Direction of CD4 T Cell Subsets. J. Immunol. 2012, 189, 721-731. [CrossRef]

30. Liu, H.; Yao, S.; Dann, S.M.; Qin, H.; Elson, C.O.; Cong, Y. ERK Differentially Regulates Th17- and Treg-cell Development and Contributes to the Pathogenesis of Colitis. Eur. J. Immunol. 2013, 43, 1716-1726. [CrossRef] [PubMed]

31. Dodeller, F.; Skapenko, A.; Kalden, J.R.; Lipsky, P.E.; Schulze-Koops, H. The P38 Mitogen-activated Protein Kinase Regulates Effector Functions of Primary Human CD4 T Cells. Eur. J. Immunol. 2005, 35, 3631-3642. [CrossRef] [PubMed]

32. Ebel, M.E.; Awe, O.; Kaplan, M.H.; Kansas, G.S. Diverse Inflammatory Cytokines Induce Selectin Ligand Expression on Murine CD4 T Cells via P38 $\alpha$ MAPK. J. Immunol. 2015, 194, 5781-5788. [CrossRef]

33. Ly, N.P.; Ruiz-Perez, B.; McLoughlin, R.M.; Visness, C.M.; Wallace, P.K.; Cruikshank, W.W.; Tzianabos, A.O.; O'Connor, G.T.; Gold, D.R.; Gern, J.E. Characterization of Regulatory T Cells in Urban Newborns. Clin. Mol. Allergy 2009, 7, 1-10. [CrossRef] [PubMed]

34. Lysechko, T.L.; Cheung, S.M.S.; Ostergaard, H.L. Regulation of the Tyrosine Kinase Pyk2 by Calcium Is through Production of Reactive Oxygen Species in Cytotoxic T Lymphocytes*. J. Biol. Chem. 2010, 285, 31174-31184. [CrossRef] [PubMed]

35. Szabó-Taylor, K.É; Eggleton, P.; Turner, C.A.L.; Faro, M.L.L.; Tarr, J.M.; Tóth, S.; Whiteman, M.; Haigh, R.C.; Littlechild, J.A.; Winyard, P.G. Lymphocytes from Rheumatoid Arthritis Patients Have Elevated Levels of Intracellular Peroxiredoxin 2, and a Greater Frequency of Cells with Exofacial Peroxiredoxin 2, Compared with Healthy Human Lymphocytes. Int. J. Biochem. Cell Biol. 2012, 44, 1223-1231. [CrossRef] [PubMed] 